\title{
Studies On Process Development And Organoleptic Evaluation Of Blended Wine From Grape, Guava and Non Juice
}

\author{
H.W. Deshpande ${ }^{1}$, S.D. Katke ${ }^{1 *}$, A.S. Kulkarni ${ }^{2}$ and A.S. Ghorband ${ }^{1}$ \\ ${ }^{1}$ Department of Food Microbiology \& Safety, College of Food Technology, VNMKV, \\ Parbhani, India. \\ ${ }^{2}$ Department of Food Processing Technology, A.D. Patel Institute of Technology, \\ Anand, Gujarat, India \\ *Corresponding author
}

\section{A B S T R A C T}

Keywords

Grape Juice,

Blended Wine,

Guava Juice,

Blended Juice, Non

Juice, Vitis vinifera,

Psidium guajava L.,

Morinda citrifolia

Article Info

Accepted:

15 December 2019

Available Online:

20 January 2020
The present study was planned to investigate the possibility of blending different fruit juices for preparation of blended wine and to observe its effects on physico-chemical, sensorial and microbiological quality. During the preparation of wine three ratio of different concentration of guava and noni were used by keeping the grape juice concentration constant, because it has more fermentable sugar compared to the others which was easily fermentable for yeast to convert them into alcohol. The blended samples along with control one was allowed to ferment for period of ten days. The different properties of the must were studied during fermentation period at $1^{\text {st }}, 5^{\text {th }}$ and $10^{\text {th }}$ day. It was concluded that blended juice wine containing grape, guava and noni juice at the concentration of 80, 10 and 10 per cent respectively was found to be more acceptable ( 7.80 score). It was also observed that alcohol content was found gradually increased up to $5^{\text {th }}$ day and decreased at slower rate after $10^{\text {th }}$ day in all samples including the control. Thus, the prepared blended juice wine was having good taste and antioxidant activity due to synergistic effect of blended fruit juices.

\section{Introduction}

India is among leading producer of fruits in the world. Global scenario diversified agroclimatic conditions built up capacity for production of a wide range of tropical, subtropical and temperate fruits. The annual production is estimated to be nearly 46 million tones accounting for about $10 \%$ of the world production notifying the shares ranging from $4 \%$ of citrus and $46 \%$ of mango fruits. It, however, contributes only $1 \%$ to the export earnings from agricultural products. Indian fruit production yields and exports grew faster 
than the average for the world production at $5.33 \%$ compared to $2.2 \%$; yields at $2.14 \%$ compared to $0.95 \%$; and exports at $8.21 \%$ compared to nearly $2 \%$. India's share in the global exports of fruits is less than $5 \%$. The global wine market remains highly fragmented with numerous small and medium sized producers in every wine producing market.

International Wine and Spirits Record listed 1,360 companies, which account for $27 \%$ of the world wine market. As with beer and spirits, top 10 wine makers produce only a small proportion of global volume i.e. $10.69 \%$ (Annon., 2004). According to the Food and Agriculture Organization (FAO), 75,866 square kilometers of the world are dedicated to grapes. Approximately $71 \%$ of world grape production is used for wine, $27 \%$ as fresh fruit, and $2 \%$ as dried fruit. A portion of grape production goes to producing grape juice to be reconstituted for fruits canned "with no added sugar" and "100\% natural". The area dedicated to vineyards is increasing by about $2 \%$ per year. The four largest wine producers are, in order of world ranking, Italy, France, Spain and the USA (Sawis., 2007).

Wine contains a number of different chemical components that influence the final product quality, and it is known to have many health benefits. The phenolic ingredient in red wine has been found to lower the incidence rate of some diseases, such as cardiovascular disease (Frankel., 1993). Also there are many flavonoids in grape juice which has antiinflammatory, antioxidant, and platelet inhibitory effects (Gryglewski., 1987). Blending of fruit juices normally done for the enhancing the color, flavor other nutritional enrichment.

It also affects the sensory characteristics of final product. Guava juice is being rich in Vit. $\mathrm{C}$ and total polyphenol which act as antioxidant and noni juice also having dark color due to anthocyanin which would definitely affect the wine made from blended fruit juices with grape juice. During the past few decades, grapes have been the main fruit for wine production. Despite that, several studies have investigated the suitability of other fruits as substrates for the purpose of wine production.

Moreover, the seasonal availability and high cost of grapes in the tropical regions has also necessitated the search for alternative fruit sources in tropical countries (Alobo and Offonry., 2009). There is abundance of tropical fruits in India which includes guava, watermelon, pineapple, plum, orange etc. These fruits are highly perishable, being susceptible to bacterial and fungal contamination, thus leading to their spoilage, mechanical damage and over ripeness. Hence, these fruits are difficult to keep for long and are utilized either as fresh or processed into juice and specialty products (Oyeleke and Olaniyan., 2007).

High rate wastage of these fruits especially at their peak of production season necessitates the need for alternative preservation and post harvest technologies towards their value addition that can reduce the level of post harvest losses besides increasing diversity of wines (Okoro., 2007; Alobo and Offonry., 2009). Guava is being rich source of ascorbic acid and having the pleasant aroma can be blended with grape juice to enrich the antioxidant activity of blended wine. Noni juice also contains dark color which may affect the blended wine.

In human health, Noni products have been shown to have antioxidant and immunestimulating properties. The phytochemicals and antioxidants are largely responsible for noni's biological action (Wang et al., 2002). Studies on antioxidants have reported the use of isolated nutrients in the treatment and prevention of diseases. However, a large variety of compounds that can act 
synergistically in protecting cells and tissues are found in foods (Bianchi and Antunes., 1999). Hence the research study was done to prepare blended juice wine at the different concentration of guava and noni juice blended with grape juice.

\section{Materials and Methods}

Fully matured and ripened Grape (Vitis vinifera) of well known variety 'Banglore blue', Guava (Psidium guajava L.) of well known variety 'Sardar' and Noni (Morinda citrifolia) were carefully selected and brought from local market. The pectinase enzyme was procured from Biocon Pvt. Ltd. Banglore and used as the clarifying agent for juice extraction.

\section{Enzymatic Extraction}

Around $1 \mathrm{~kg}$ of ripened fruits were taken as experimental material. The fruits were deseeded. Inedible portion of the fruits was weighed to calculate waste index. The steam blanching (at $45^{\circ} \mathrm{C}$ for $5 \pm 10 \mathrm{~min}$ ) to all fruit was done and subjected for liquefaction. A known quantity $(100 \mathrm{~g})$ pre processed fruit pulp was taken in a $500 \mathrm{ml}$ capacity beaker. To preserve the natural quality, sodium benzoate for grape and guava at the rate of $250 \mathrm{ppm}$ was added (Bahadur et al.) The enzyme in proportion $(0.245 \%)$ was added in fleshy pulp to facilitate liquefaction process.

Liquefaction process is standardized under controlled conditions like incubation time $4 \mathrm{hr}$ for grape, and $6 \mathrm{hr}$ for guava (Pooja et al., $2011)$ and temperature $\left(40^{\circ} \quad \mathrm{C}\right)$. The liquefied pulp in the form of homogeneous puree after treatment extraction was done by pressing and decanting through double layer of muslin cloth. Clarified juice was used for further research.

Preparation of fruit juice blends for preparation of wine.

The clarified fruit juices were blended at the various ratios of grape, guava and noni juice and used for preparation of wine. During the preparation of wine three ratio of different concentration of guava and noni were used by keeping the grape juice concentration constant because it has more fermentable sugar compared to the others which was easily fermentable for yeast to convert them into alcohol. The changes in physicochemical composition of three blends were compares with control which was having 100 percent grape juice for fermentation. During the preparation of wine total soluble solids was maintained $24^{0} \mathrm{Bx}$ by adding the sugar and titrable acidity was maintained $0.7 \%$ because it is feasible for yeast to ferment sugar into alcohol and proper color and flavor development.

\section{Recipe for wine preparation}

The Flow chart (Fig.1) shows that recipe having fruit juice compressed yeast and sugar were used for wine preparation.

\section{Results and Discussion}

\section{Preparation of Blended juice wine}

In order to prepare the wine, three different concentrations of blended juices and control sample containing 100 per cent grape juice were fermented for 10 days at standard conditions. The different properties of the must were studied during fermentation period.

Changes in chemical properties of must during fermentation

The chemical properties of must were recorded under $1^{\text {st }}, 5^{\text {th }}$ and $10^{\text {th }}$ days of fermentation and the data is presented in Table 7. The data presented in above Table 7 shows that alcohol content of control wine and blended juice wine were initially high at 5 day and then decreased at slower rate. Alcohol content of control wine at first day was nil and 
as fermentation goes on the alcohol content was found increases at $5^{\text {th }}$ day i.e. 12.80 percent and at 10 day there was little low alcohol content 12.63 percent due to change in specific gravity $1,0.9820,0.9830$ respectively. The variation in the alcohol content may be due to utilization of sugar by yeast during the fermentation process.

No et al. (2008) reported that ethanol content of four red wines after 5 days fermentation were in the range of 11.6 to 12.4 percent .Similarly for sample A alcohol content at first day, 5 days and 10 days was found nil, 11.90 percent, 11.73 percent at specific gravity $0.0 .9839,0.9841$ respectively. It was found that from above table that as the specific gravity of wine decreases the alcohol content in the wine increases. Mulero et al. (2010) also calculated the alcohol content in conventional wine and organic wine based on specific gravity. Alcohol content Sample B at first day, 5 days and 10 days was found nil, 11.65 percent, 11.49 percent at specific gravity $0.0,0.9842,0.9844$ respectively. Alcohol content of sample $\mathrm{C}$ at $1^{\text {st }}$ day, 5 days and 10 days was found nil, 11.90 percent, 11.73 percent at specific gravity 0.0.9843, 0.9846 respectively. Joshi et al. (2011) also reported that table wine alcohol content ranges from 11 to 14 percent.

The titrable acidity of any fruit wine is an important characteristics varying between $(0.5$ to $1.0 \%$ ). Titrable acidity and $\mathrm{pH}$ of control wine during fermentation process was found in the range 0.653 to 0.70 percent and 3.49 to 3.58 respectively. During the fermentation process there was decrease in acidity and increase in $\mathrm{pH}$. However for sample A titrable acidity and $\mathrm{pH}$ was found in the range of 0.67 to 0.70 percent and 3.55 to 3.56 . For sample B Titrable acidity and $\mathrm{pH}$ was found in the range 0.671 to 0.70 percent and 3.53 to 3.55 . For sample $\mathrm{C}$ Titrable acidity and $\mathrm{pH}$ was found in the range 0.679 to 0.70 percent and 3.51 to 3.53. During the fermentation process there was decrease $\mathrm{pH}$ in all wines and was may be due to metabolic activity of microorganisms, nitrogen source can significantly affect $\mathrm{pH}$ therefore $\mathrm{pH}$ of the medium must be adjusted carefully.

During the alcoholic fermentation reducing sugar was found drastically decreased because yeast had utilized it .The reducing sugar content of control wine at first, 5, and 10 days were found $11.50,0.16$ and 0.15 percent more ever blend A having 9.76, 0.31, 0.24 percent , blend $\mathrm{B}$ having 9.66, 0.22, 0.20 percent and blend $\mathrm{C}$ having 9.57,0.23, 0.22 percent respectively. The result pertaining to the reducing sugar content in the wine was in the tune of Jiangfei Meng et al. (2012) and reported the range 0.18 to $0.247 \%$. The tannic acid content of blended juices at first day, 5 days and 10 days fermentation was found in decreasing manner. The tannic acid content of control, blend $\mathrm{A}$, bled $\mathrm{B}$ and blend $\mathrm{C}$ in the range of 0.15 to $0.17,0.19$ to $0.23,0.17$ to 0.21 percent respectively. Dharmadhikari (2011) also reported tannic acid content in red wine 0.1 to 0.3 percent.

Antioxidant constituents and activity of control and blended juices

The ascorbic acid content of blended juice samples was found to be increased as guava juice has been added in the blending. It was found highest $27.16 \mathrm{mg} / 100 \mathrm{~g}$ in sample A than sample B $(20.94 \mathrm{mg} / 100 \mathrm{~g})$ and C $(13.76 \mathrm{mg} / 100 \mathrm{~g})$. The total anthocyanin content of control black grape juice was found to be highest $(46.45 \mathrm{mg} / 100 \mathrm{ml})$ followed by blend C $(40.27 \mathrm{mg} / 100 \mathrm{ml})$ and blend B $(39.17 \mathrm{mg} / 100 \mathrm{ml})$ and bend A $(38.38 \mathrm{mg} / 100 \mathrm{ml})$. Total polyphenol content of juices from control $\mathrm{A}, \mathrm{B}$ and $\mathrm{C}$ were found $245.20,250.59$ and $246.85,243.34 \mathrm{mg} / 100 \mathrm{ml}$ respectively. The percent inhibition by DPPH was found to be $48.35,50.30,49.25$ and 47.60 for control, A, B and C respectively. 
Fig.1 Flowsheet for preparation of wine

Receiving of fruits (Grapes, Guava and Noni)

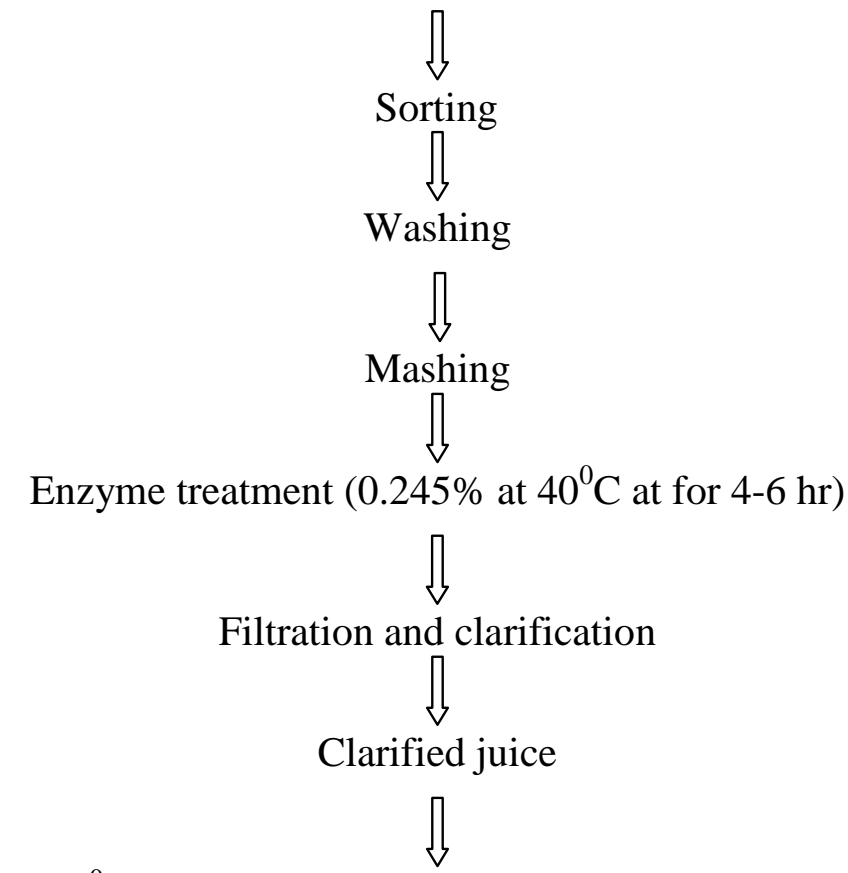

Ameliorated juice (TSS $24^{0} \mathrm{Bx}$ and acidity 0.7\%) [Sacchromyces cervicsae culture @ 4\% (v/v)]

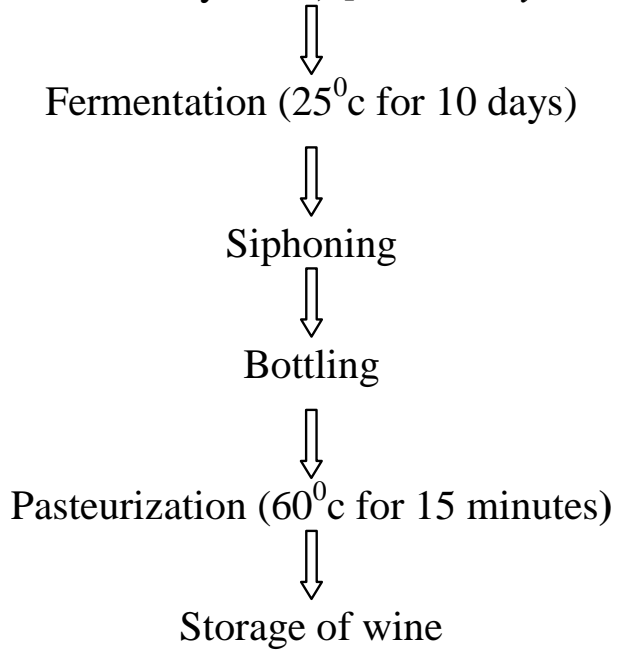

Table.1 Preparation of fruit juice blends

\begin{tabular}{|c|c|c|c|c|}
\hline Clarified Juice & \multicolumn{4}{|c|}{ Quantity of Juice (\%) } \\
\cline { 2 - 5 } & Control & A & B & C \\
\hline Grape juice & 100 & 80 & 80 & $\mathbf{8 0}$ \\
\hline Guava juice & 0 & 15 & 10 & $\mathbf{0 5}$ \\
\hline Noni juice & $\mathbf{0}$ & $\mathbf{5}$ & $\mathbf{1 0}$ & $\mathbf{1 5}$ \\
\hline
\end{tabular}


Table.2 Recipe for wine preparation

\begin{tabular}{|c|c|c|}
\hline $\begin{array}{c}\text { Sr. } \\
\text { No. }\end{array}$ & Ingredients & Quantity \\
\hline 1 & Fruit juices & $\mathbf{1 0 0 \%}$ \\
\hline 2 & Compressed yeast & $\mathbf{4 \%}$ \\
\hline 3 & Sugar & $\mathbf{2 4 \%}$ \\
\hline
\end{tabular}

Table. 3 Physical characteristics of fresh fruits

\begin{tabular}{|c|c|c|c|c|}
\hline $\begin{array}{c}\text { Sr. } \\
\text { No. }\end{array}$ & Parameters & \multicolumn{3}{|c|}{ Fruits } \\
\hline $\mathbf{1 .}$ & Color & Gurple to black & $\begin{array}{c}\text { Guava } \\
\text { Yellowish } \\
\text { green }\end{array}$ & Dark green \\
\hline $\mathbf{2 .}$ & Shape & Oblong & $\begin{array}{c}\text { Round or } \\
\text { Ovoid }\end{array}$ & Oval / Oblong \\
\hline 3. & Avg. weight per fruit $(\mathrm{g})$ & 5.50 & 135.0 & $\mathbf{2 5 . 4}$ \\
\hline $\mathbf{4 .}$ & Waste index $(\%)$ & 6.40 & 31.4 & $\mathbf{3 8 . 9}$ \\
\hline $\mathbf{5 .}$ & Edible index $(\%)$ & $\mathbf{9 3 . 6 0}$ & $\mathbf{6 9 . 6}$ & $\mathbf{5 1 . 6}$ \\
\hline
\end{tabular}

Table.4 Chemical Composition of fresh fruits

\begin{tabular}{|c|c|c|c|c|}
\hline \multirow{2}{*}{$\begin{array}{c}\text { Sr. } \\
\text { No. }\end{array}$} & Constituents (\%) & \multicolumn{3}{|c|}{ Fruits } \\
\hline $\mathbf{1}$ & & Grape & Guava & Noni \\
\hline $\mathbf{2}$ & Moisture & 84.00 & 83.00 & $\mathbf{9 1 . 0 0}$ \\
\hline $\mathbf{3}$ & Protein & 0.62 & 1.37 & $\mathbf{0 . 8 5}$ \\
\hline $\mathbf{4}$ & Fat & 0.38 & 0.57 & $\mathbf{0 . 1 8}$ \\
\hline $\mathbf{5}$ & Total carbohydrate & 15.10 & 14.23 & $\mathbf{4 . 9 0}$ \\
\hline $\mathbf{6}$ & Ash & 0.32 & 0.73 & $\mathbf{0 . 4 0}$ \\
\hline
\end{tabular}

Table.5 Physicochemical properties of raw and clarified fruit juices

\begin{tabular}{|l|c|c|c|c|c|c|c|}
\hline \multirow{2}{*}{$\begin{array}{l}\text { Sr. } \\
\text { No. }\end{array}$} & \multirow{2}{*}{ Parameters } & \multicolumn{6}{|c|}{ Fruit juices } \\
\cline { 3 - 8 } & & \multicolumn{2}{|c|}{ Grape } & \multicolumn{2}{c|}{ Guava } & \multicolumn{2}{|c|}{ Noni } \\
\cline { 3 - 8 } & & Raw & Clarified & Raw & Clarified & Raw & Clarified \\
\hline $\mathbf{1}$ & Yield (\%) & 76 & 89.30 & 65.42 & 85.20 & 40.17 & $\mathbf{5 1 . 0 8}$ \\
\hline $\mathbf{2}$ & T.S.S ( $\left.{ }^{(} \mathrm{Bx}\right)$ & 14.5 & 14.65 & 8.3 & 8.4 & 8.6 & $\mathbf{8 . 6 3}$ \\
\hline $\mathbf{3}$ & Titrable Acidity (\%) & 0.82 & 0.86 & 0.59 & 0.64 & 1.25 & $\mathbf{1 . 2 7}$ \\
\hline $\mathbf{4}$ & pH & 3.55 & 3.49 & 4.2 & 4.12 & 3.58 & $\mathbf{3 . 5 1}$ \\
\hline $\mathbf{5}$ & Total sugar (\%) & 13.64 & 13.78 & 10.20 & 10.40 & 3.40 & $\mathbf{3 . 3 9}$ \\
\hline $\mathbf{6}$ & Reducing sugar (\%) & 11.33 & 11.40 & 3.17 & 3.22 & 1.31 & $\mathbf{1 . 3 5}$ \\
\hline $\mathbf{7}$ & Non reducing sugar (\%) & $\mathbf{2 . 1 9}$ & $\mathbf{2 . 2 6}$ & $\mathbf{6 . 6 7}$ & $\mathbf{6 . 8 2}$ & $\mathbf{1 . 9 8}$ & $\mathbf{2 . 0 4}$ \\
\hline
\end{tabular}


Table.6 Chemical properties of control and blended juice

\begin{tabular}{|c|c|c|c|c|c|}
\hline \multirow[t]{2}{*}{$\begin{array}{l}\text { Sr. } \\
\text { No. }\end{array}$} & \multirow[t]{2}{*}{ Parameters } & \multicolumn{4}{|c|}{$\begin{array}{c}\text { Juice Sample } \\
\text { (Grape: Guava: Noni) }\end{array}$} \\
\hline & & $\begin{array}{c}\text { Control } \\
\text { (100:0:0) }\end{array}$ & $\begin{array}{c}A \\
(80: 15: 5)\end{array}$ & $\begin{array}{c}\text { B } \\
(80: 10: 10)\end{array}$ & $\begin{array}{c}C \\
(80: 5: 15)\end{array}$ \\
\hline 1 & T.S.S $\left({ }^{0} \mathrm{Bx}\right)$ & 14.65 & 12.7 & 13.2 & 13.5 \\
\hline 2 & Titrable Acidity (\%) & 0.86 & 0.83 & 0.85 & 0.87 \\
\hline 3 & $\mathrm{pH}$ & 3.49 & 3.55 & 3.53 & 3.51 \\
\hline 4 & Total sugar (\%) & 13.64 & 12.75 & 12.70 & 12.05 \\
\hline 5 & Reducing sugar (\%) & 11.50 & 9.76 & 9.66 & 9.57 \\
\hline
\end{tabular}

Table.7 Changes in chemical properties during fermentation

\begin{tabular}{|c|c|c|c|c|c|}
\hline $\begin{array}{l}\text { Sr. } \\
\text { No. }\end{array}$ & Parameter & Control & $\mathbf{A}$ & B & $\mathbf{C}$ \\
\hline \multicolumn{6}{|c|}{ On $1^{\text {st }}$ day of Fermentation } \\
\hline 1 & Alcohol (\%) & 0.00 & 0.00 & 0.00 & 0.00 \\
\hline 2 & Sp gravity & 1.00 & 1.00 & 1.00 & 1.00 \\
\hline 3 & $\begin{array}{l}\text { Titrable Acidity } \\
(\%)\end{array}$ & 0.70 & 0.70 & 0.70 & 0.70 \\
\hline 4 & $\mathrm{pH}$ & 3.49 & 3.55 & 3.53 & 3.51 \\
\hline 5 & Reducing sugar (\%) & 11.50 & 9.76 & 9.66 & 9.57 \\
\hline 6 & Tannic acid (\%) & 0.17 & 0.23 & 0.22 & 0.21 \\
\hline \multicolumn{6}{|c|}{ On $5^{\text {th }}$ Day of Fermentation } \\
\hline 1 & Alcohol (\%) & 12.80 & 11.90 & 11.65 & 11.57 \\
\hline 2 & Sp gravity & 0.9820 & 0.9839 & 0.9842 & 0.9843 \\
\hline 3 & $\begin{array}{l}\text { Titrable Acidity } \\
(\%)\end{array}$ & 0.657 & 0.672 & 0.674 & 0.681 \\
\hline 4 & $\mathrm{pH}$ & 3.57 & 3.55 & 3.55 & 3.52 \\
\hline 5 & Reducing sugar (\%) & 0.22 & 0.24 & 0.22 & 0.23 \\
\hline 6 & Tannic acid (\%) & 0.16 & 0.21 & 0.20 & 0.19 \\
\hline \multicolumn{6}{|c|}{ On $10^{\text {th }}$ Day of Fermentation } \\
\hline 1 & Alcohol (\%) & 12.63 & 11.73 & 11.49 & 11.45 \\
\hline 2 & Sp gravity & 0.9830 & 0.9841 & 0.9844 & 0.9846 \\
\hline 3 & $\begin{array}{l}\text { Titrable Acidity } \\
(\%)\end{array}$ & 0.653 & 0.67 & 0.671 & 0.679 \\
\hline 4 & $\mathrm{pH}$ & 3.58 & 3.56 & 3.55 & 3.53 \\
\hline 5 & Reducing sugar (\%) & 0.18 & 0.21 & 0.201 & 0.222 \\
\hline 6 & Tannic acid (\%) & 0.15 & 0.19 & 0.19 & 0.17 \\
\hline
\end{tabular}


Table.8 Antioxidant constituents and activity of raw and clarified juices

\begin{tabular}{|c|c|c|c|c|c|c|c|}
\hline \multirow{2}{*}{$\begin{array}{c}\text { Sr. } \\
\text { No. }\end{array}$} & Parameters & \multicolumn{2}{|c|}{ Grape } & \multicolumn{2}{|c|}{ Guava } & \multicolumn{2}{|c|}{ Noni } \\
\hline $\mathbf{1}$ & Raw & Clarified & Raw & Clarified & Raw & Clarified \\
\hline & $\begin{array}{c}\text { Ascorbic acid } \\
(\mathrm{mg} / 100 \mathrm{ml})\end{array}$ & 4.20 & 3.90 & 172.00 & 158.24 & 20.10 & $\mathbf{1 8 . 2 0}$ \\
\hline $\mathbf{2}$ & TA (mg/100ml) & 46.20 & 46.50 & 0.19 & 0.18 & 17.00 & $\mathbf{1 7 . 2 3}$ \\
\hline $\mathbf{3}$ & TP (mg.GAE/100ml) & 230.90 & 245.30 & 282.50 & 298.4 & 210.00 & $\mathbf{2 1 2 . 0 0}$ \\
\hline $\mathbf{4}$ & $\begin{array}{c}\text { Inhibition by DPPH } \\
(\mathbf{\%})\end{array}$ & $\mathbf{4 6 . 2 2}$ & $\mathbf{4 8 . 4 3}$ & $\mathbf{5 6 . 5 4}$ & $\mathbf{5 9 . 0 3}$ & $\mathbf{4 2 . 0 3}$ & $\mathbf{4 3 . 5 5}$ \\
\hline
\end{tabular}

TA: Total Anthocyanin; TP: Total Phenol; DPPH: (2, 2-diphenyl-1- picrylhydrazyl)

Table.9 Antioxidant constituents and activity of control and blended juices

\begin{tabular}{|c|c|c|c|c|c|}
\hline $\begin{array}{c}\text { Sr. } \\
\text { No. }\end{array}$ & Parameters & $\begin{array}{c}\text { Control } \\
(\mathbf{1 0 0 : 0 : 0 )}\end{array}$ & $\begin{array}{c}\mathbf{A} \\
(\mathbf{8 0 : 1 5 : 5 )}\end{array}$ & $\begin{array}{c}\mathbf{B} \\
(\mathbf{8 0 : 1 0 : 1 0})\end{array}$ & $\begin{array}{c}\mathbf{C} \\
\mathbf{( 8 0 : 5 : 1 5 )}\end{array}$ \\
\hline $\mathbf{1}$ & $\begin{array}{c}\text { Ascorbic } \\
\text { acid(mg/100g) }\end{array}$ & 3.90 & 27.16 & 20.94 & $\mathbf{1 3 . 7 6}$ \\
\hline $\mathbf{2}$ & TA (mg/100ml) & 46.45 & 38.38 & 39.17 & $\mathbf{4 0 . 2 7}$ \\
\hline $\mathbf{3}$ & TP (mg.GAE/100ml) & 245.20 & 250.59 & 246.85 & $\mathbf{2 4 3 . 3 4}$ \\
\hline $\mathbf{4}$ & $\begin{array}{c}\text { Inhibition by DPPH } \\
(\mathbf{\%})\end{array}$ & $\mathbf{4 8 . 3 5}$ & $\mathbf{5 0 . 3 0}$ & $\mathbf{4 9 . 2 5}$ & $\mathbf{4 7 . 6 0}$ \\
\hline
\end{tabular}

TA: Total Anthocyanin; TP: Total Phenol; DPPH: (2, 2-diphenyl-1- picrylhydrazyl)

Table.10 Antioxidant constituents and activity of wine

\begin{tabular}{|c|c|c|c|c|c|}
\hline $\begin{array}{c}\text { Sr. } \\
\text { No. }\end{array}$ & Parameters & $\begin{array}{c}\text { Control } \\
(\mathbf{1 0 0 : 0 : 0 )}\end{array}$ & $\begin{array}{c}\mathbf{A} \\
(\mathbf{8 0}: \mathbf{1 5}: \mathbf{5})\end{array}$ & $\begin{array}{c}\text { B } \\
(\mathbf{8 0 : 1 0 : 1 0 )}\end{array}$ & $\begin{array}{c}\mathbf{C} \\
(\mathbf{8 0 : 5}: \mathbf{1 5})\end{array}$ \\
\hline $\mathbf{1}$ & $\begin{array}{c}\text { Ascorbic } \\
\text { acid(mg/100g) }\end{array}$ & 1.92 & 14 & 12.20 & $\mathbf{7 . 4 0}$ \\
\hline $\mathbf{2}$ & TA (mg/100ml) & 48.70 & 40.42 & 39.73 & $\mathbf{4 2 . 2 8}$ \\
\hline $\mathbf{3}$ & TP (mg.GAE/100ml) & 285.30 & 313.70 & 297.20 & $\mathbf{2 8 3 . 5 0}$ \\
\hline $\mathbf{4}$ & $\begin{array}{c}\text { Inhibition by DPPH } \\
(\mathbf{\%})\end{array}$ & $\mathbf{5 7 . 7 0}$ & $\mathbf{6 2 . 7 0}$ & $\mathbf{5 9 . 2 4}$ & $\mathbf{5 7 . 1 0}$ \\
\hline
\end{tabular}

TA: Total Anthocyanin; TP: Total Phenol; DPPH: (2, 2-diphenyl-1- picrylhydrazyl)

Table.11 Organoleptic evaluation of wine prepared with different blending levels of fruit juices

\begin{tabular}{|c|c|c|c|c|c|c|c|}
\hline Sr. No. & Sample & Color & Appearance & Taste & Flavour & Mouthfeel & Overall acceptability \\
\hline $\mathbf{1}$ & Control & 8.25 & 8.24 & 8.40 & 8.23 & 8.40 & $\mathbf{8 . 2 5}$ \\
\hline $\mathbf{2}$ & A & 7.10 & 6.70 & 6.40 & 7.00 & 7.30 & $\mathbf{7 . 0 0}$ \\
\hline $\mathbf{3}$ & B & 7.20 & 7.15 & 7.00 & 7.50 & 8.00 & $\mathbf{7 . 8 0}$ \\
\hline $\mathbf{4}$ & C & 7.00 & 6.15 & 6.50 & 6.15 & 6.50 & $\mathbf{6 . 0 0}$ \\
\hline $\mathbf{5}$ & SE \pm & 0.11 & 0.05 & 0.17 & 0.05 & 0.05 & $\mathbf{0 . 0 4}$ \\
\hline $\mathbf{6}$ & CD at 5\% & $\mathbf{0 . 3 7}$ & $\mathbf{0 . 1 8}$ & $\mathbf{0 . 5 4}$ & $\mathbf{0 . 1 8}$ & $\mathbf{0 . 1 6}$ & $\mathbf{0 . 1 3}$ \\
\hline
\end{tabular}


Table.12 Microbial quality of wine (Sample B) from blended juice

\begin{tabular}{|c|c|c|}
\hline $\begin{array}{c}\text { Sr. } \\
\text { No. }\end{array}$ & Parameter & CFU/g \\
\hline 1 & Total plate count & $\mathbf{1 . 8 ~ x 1 0}^{\mathbf{2}}$ \\
\hline $\mathbf{2}$ & Yeast and mold count & $\mathbf{3 . 4}^{\mathbf{2}} \mathbf{1 0}^{\mathbf{2}}$ \\
\hline $\mathbf{3}$ & Coliform count & $\mathbf{1 . 1}^{\mathbf{1}} \mathbf{1 0}^{\mathbf{1}}$ \\
\hline
\end{tabular}

\section{Antioxidant constituents and activity of} wine

The result revealed in Table 10 shows that the ascorbic acid content which was found in the range of 1.92 to $7.40 \mathrm{mg} / 100 \mathrm{mg}$. The lowest ascorbic content was found in the control sample while highest ascorbic acid content was found sample A. Similar study for ascorbic acid content in guava wine was studied by Pooja et al., (2011).

The reducing sugar content of wine was found in the range of 0.179 to 0.222 . It is revealed from above table that the anthocyanin content of the wine ranges from 39.73 to $48.70 \mathrm{mg} / 100 \mathrm{ml}$ while highest in control wine $48.70 \mathrm{mg} / 100 \mathrm{ml}$ followed by $42.28 \mathrm{mg} / 100 \mathrm{ml}$ in the $\mathrm{C}$ and $40.42 \mathrm{mg} / 100 \mathrm{ml}$ in the A and $39.73 \mathrm{mg} / 100 \mathrm{ml}$ in the A.

The increase in the anthocyanin may be due to vilification process. The total phenolic content of A was found highest 3313.7 $\mathrm{mg} / 100 \mathrm{ml}$ and lowest in the $\mathrm{C} 283 \mathrm{mg} / 100 \mathrm{ml}$ and $297.20 \mathrm{mg} / 100 \mathrm{ml}$ in the B and 285 in the control wine. The total phenolic (TP) content of red wine is about 100 to $400 \mathrm{mg} / 100 \mathrm{ml}$, while it ranges from 200 to $500 \mathrm{mg} / 100 \mathrm{ml}$ in white wines The polyphenolic compounds in wine are affected by grape extraction time, fermentation time, squeeze level, clarification aging process of wine after it is bottled. (Li et al., 2009). The percent inhibition by DPPH was found in the range of 57.08 to 62.70 . The values were found $51.10,53.15,52.12$ and 50.54 percent for control wine and for A, B, C respectively. Similar type of study was done by No et al., (2008) for percent inhibition for wines made from four varieties of grapes.

Organoleptic characteristics of prepared wine

After completion of fermentation for the period of 10 days, the must was filtered using whatman's filter paper and organoleptic properties of prepared wine was evaluated and the mean values are presented in Table 11.

The overall acceptability of the wine prepared by blend B had greater acceptability followed the control wine. Other treatment was significantly different from the control as well as treatment $\mathrm{B}$.

Microbial quality of blended fruit juice wine

Microbial quality is important aspect in determining the spoilage of wine. It is revealed from above table that total plate count in the sample B was found to be 1.8 $\mathrm{x} 10^{2} \mathrm{CFU} / \mathrm{g}$. The yeast and mold count were found to be $3.4 \times 10^{2} \mathrm{CFU} / \mathrm{g}$ as the favorable medium was available for the growth of yeast and mold. The coliform count in the sample B wine was found to be $1.1 \times 10^{1} \mathrm{CFU} / \mathrm{g}$ and found lower because noni juice is having antibacterial nature.

Thus in the light of the scientific data of the present investigation, it may be concluded that blended juice wine containing grape, guava and noni juice at the concentration of 
80, 10 and 10 per cent respectively was found to be more acceptable with 59.24 percent antioxidant activity.

\section{References}

A.O.A.C., 1990. Official methods of analysis. Association of official analytical chemists. $\quad 15^{\text {th }}$ edition. Washington D.C.

Alobo AP, Offonry SU (2009). Characteristics of colored wine produced from Roselle (Hibiscus sabdariffa) calyx extract. J. Inst. Brew., 115: $91-94$.

Anonymous(2004). International Wine and Spirit Record.

Bahadur V., Mishra D., Singh D.B. and Roshan R.K. (2010). Effect of varieties and preservative levels on shelf life of aonla juice. J. Hort. 876, 373- 380.

Bianchi M.L.P., Antunes, L.M.G.(1999). Radicais livreseos principais antioxidants da dieta. Rev. Nutr., v.12, p.123- 130.

Dharmadhikari M.R (2011). The Northern Grapes Project by the USDA's Specialty Crops Research Initiative Program of the National Institute for Food and Agriculture, Project 201151181-30850.

Frankel EN, Kanner J, German JB, Parks E, Kinsella JE. (1993). Inhibition of oxidationof human low-density lipoprotein by phenolic substances in red wine. Lancet 341: 454- 457.

Gryglewski RJ (1987). On the mechanism of antithrombotic action of flavonoids.

Biochem. Pharmacol. 36: 317-322.

Jiangfei Meng, Yulin Fang, Jinshan Gao, Lingling Qiao Ang Zhang (2012). Phenolics Compositionand

Antioxident Activity of Wine Produced from Spine Grape (Vitis davidii Foex) and Cherokee Rose (Rosa laevigata Michx.) Fruits from South
China. Journal of Food Sciences, Vol71,No1

Joshi V.K. Parmar Mukesh and Rana Neerja (2011). Purification and charaacterisation of pectinase

produced from apple pomace and evaluation of its its efficacy in fruit juice extraction and clarification. Indian Journal of natural products and Resources Vol. 2(2), pp189- 197.

Li H. Wang XY. Li Y. Li PH. Wang H. (2009). Polyphenolic compounds and antioxidant properties of selected china wines. Food Chem112:454- 60.

Mulero Juana, Pardo Francisco, Zafrilla Pilar (2010). Antioxidat activity and phenolic composition of organic and conventional grape wines.Journal of Food Composition and Analysis 23, 569-574.

No, Jae-Duck, Dae-Hyoung Lee, Young-Soo Hwang, Sang-Han Lee,Dae-Hyung Lee, and Jong-Soo Lee. (2008). Changes of Physicochemical Properties and Antioxidant Activities of Red Wines during Fermentation and Post-fermentation Kor. J. Microbiol. Biotechnol. Vol. 36, No. 1, 67-71.

Okoro CE (2007). Production of red wine from roselle (Hibiscuss abdariffa) and pawpaw (Carica papaya) using palmwine yeast (Saccharomyce scerevisiae). Niger. Food J., 25: 158-164.

Oyeleke FI, Olaniyan AM. (2007). Extraction of juice from some tropical fruitsusing a small scale multi-fruit juice extractor. Afr. Crop Sci.

Pooja and Gurvinder Singh Kocher (2011). Status of wine production from guava (Psidium L.): A traditional fruit of India African Journal of Food Science Vol 5(16), pp. 851- 860.

SAWIS: South African Wine Industry Statistics Nr 31. (2007). SA Wine 
Industry Information Services).

Wang, J.S., Wang J and Gulfraz M. (2005). Efficient Cellulase Production from Corn Straw by Trichoderma Reesei LW1 through Solid StateFermentation Process.
Wang M. -Y., West B. J., Jensen C. J., Nowicki D., Su C., Palu A. K., et al.(2002). Morinda citrifolia (Noni): A literature review and recent advances in Noni research. Acta Pharmacologica Sinica, 12, 11271141.

\section{How to cite this article:}

Deshpande H.W, S.D. Katke, A.S. Kulkarni and Ghorband. A.S. 2020. Studies on Process Development and Organoleptic Evaluation of Blended Wine from Grape, Guava and Non Juice. Int.J.Curr.Microbiol.App.Sci. 9(01): 1288-1298.

doi: https://doi.org/10.20546/ijcmas.2020.901.142 